\title{
GROWTH OF THE RUBIA TINCTORUM L (PAINTED PIGEON) PLANT AND ITS ROLE IN THE NATIONAL ECONOMY, THE COMPOSITION, BIOLOGICAL FEATURES AND EXTRACTS OF MICRO AND MACROELEMENTS
}

\author{
A.ISHMURATOVA ${ }^{1 *}$, A.ISLOMOV ${ }^{2}$, D.KHOLMURODOVA ${ }^{3}$, S.PARDAEVA ${ }^{4} \&$ Z.SAIDMURODOVA ${ }^{5}$ \\ ${ }^{1,3,4,5}$ Teacher of the Department of Medicine and Biochemistry of Samarkand Medical Institute, Samarkand, Uzbekistan
}

${ }^{2}$ Institute of Bioorganic Chemistry named after academician A.S. Sadykov of the Academy of Sciences of Uzbekistan, Tashkent,

\section{Uzbekistan}

\begin{abstract}
This article presents the methods, biological features, and micro and macro elements for growing the medicinal plant Rubia tinctorum, which grows in the Zeravshan Valley. It describes the use of the Rubia tinctorum plant in medicine and the national economy, as well as the use of natural chemicals isolated from the Rubia tinctorum plant as natural dyes for the production of yarn, fabrics, silkworm materials and cotton products.

KEYWORDS: Rubia Tinctoru L, Rubia Iberica, Anthracene, Alizarin, Ruberitric Acid, Haliosin, Purpurin, Xanthopurpurin, Pseudopurpurin, Rubiadin Glucoside, Munistin, Lucidin, Ibericin, Gallstone, Kidney, Stone, Kidney, Tissue, Natural Dye
\end{abstract}

Received: Jun 08, 2020; Accepted: Jun 28, 2020; Published: Sep 18, 2020; Paper Id.: IJMPERDJUN20201329

\section{INTRODUCTION}

It is well-known that the biology of the Rubia tinctorum plant, which has been used for many years by humans, has prompted the cultivation of promising species and the protection of rare species, and the $\mathrm{V}$ principles of the "strategy of action" in the field of science and technology. Pharmacology". At the same time, creation of the first raw-material base for the preparation of low-quality and import-substituting medicines by separating natural medicines from local raw materials is of great importance. These medicines can be used in medical practice and in the national economy by isolating native medicinal plants.

\section{Theoretical part}

Painted rosé - Rubia tinctorum L. and Georgia rosemary Rubia iberica C. Koch. (Rubia tinctorum L. var. Iberica Fisch. Ex DC) occurrences - belongs to the Rubicaeae family. It is found in Ukraine, Moldova, south-southeast of Russia, Caucasus (Azerbaijan, Georgia, Armenia, Dagestan) and Central Asia. In Uzbekistan, it grows mainly on ditches, bushes, canals, fields and gardens. The product is mainly produced in Dagestan, in the northeast of Azerbaijan, and in Chechnya-Ingushetia. [1-4]

Rubia tinctorum species is a perennial herbaceous plant that is $30-150 \mathrm{~cm}$ tall. The rhizome is long, reptile, branched, cylindrical, thick, jointed, multi-headed. The leaves are ovate-shaped, shiny, with a large vein on the underside. The flowers are small, greenish-yellow, in a semi-umbrella of leaves, and form an oval bouquet. The wallpaper is undiscovered, with five crowns, a single, voronic-wheeled wheel, 5 pallets, and a mother bedroom 2 
bed. The fruit is 1-2 spherical, spherical, initially wet, the fruit turns red and then turns black. Flowering in June-August, fruit - August-September ripening, Rubia tinctorum Seed top of the soil Figure 1. [1-4]

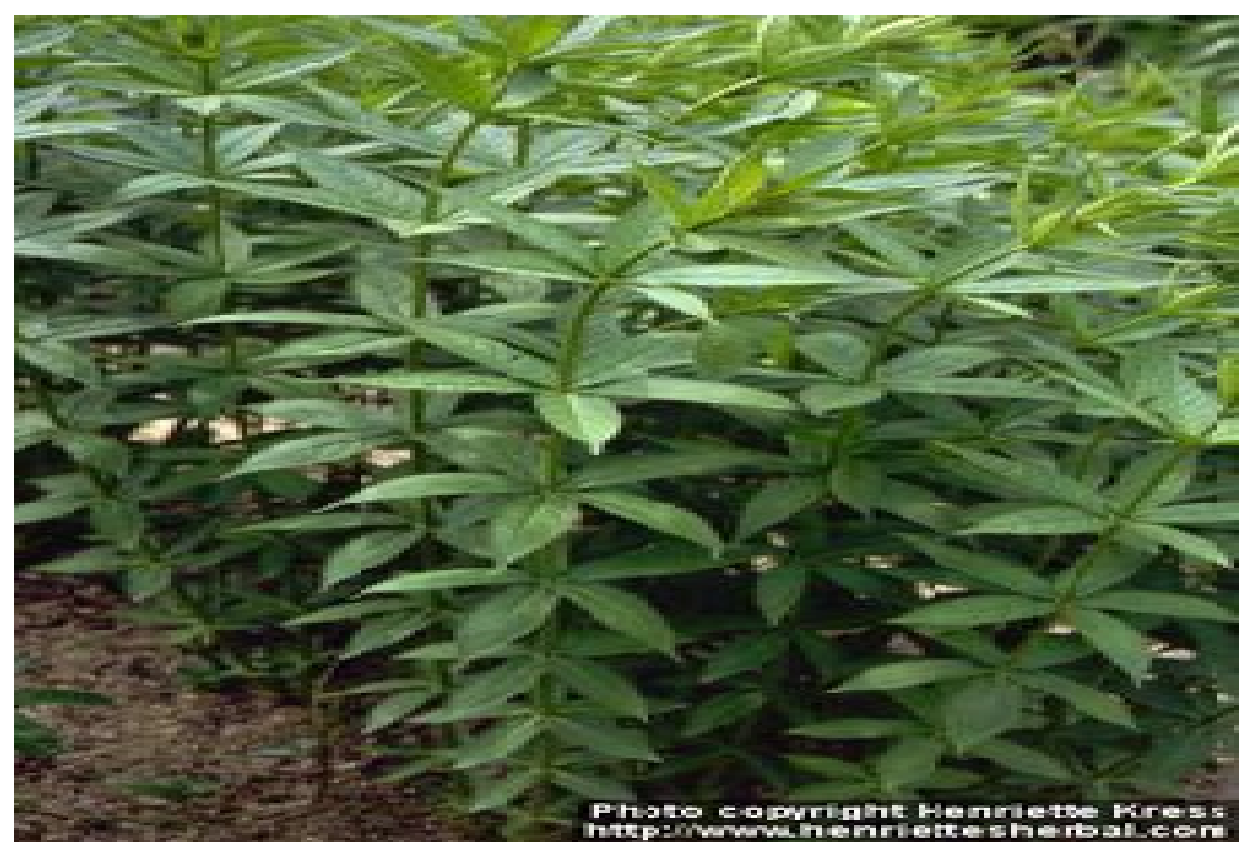

Figure 1: Rubia tinctorum Grass upper part

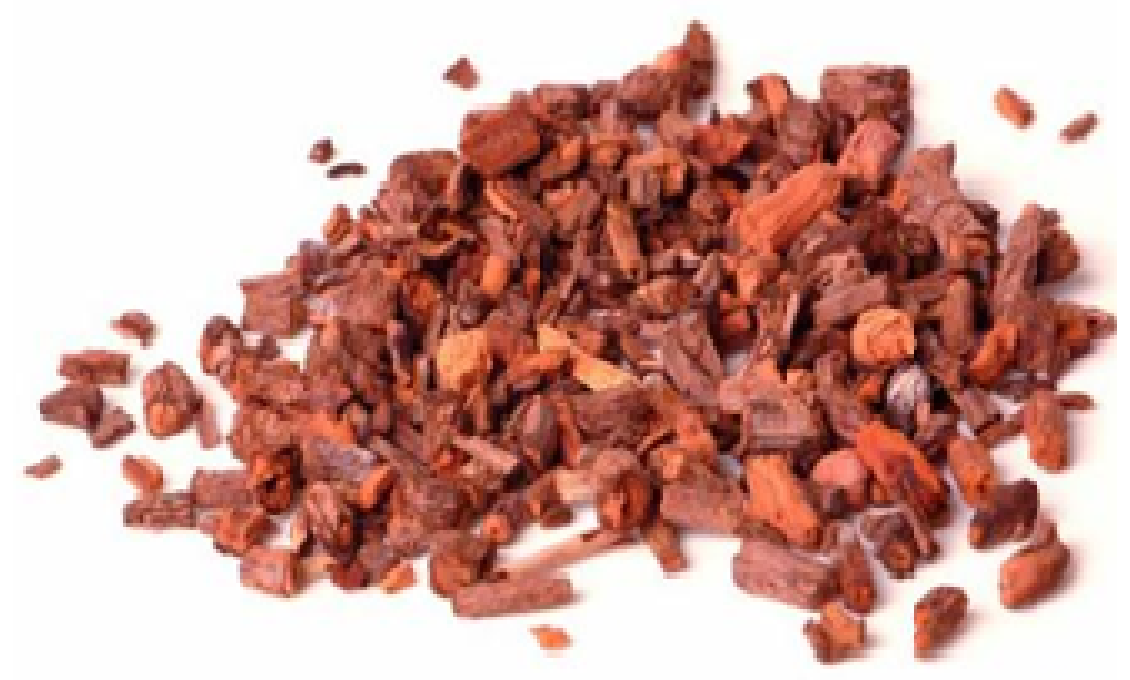

Figure 2. Underneath the Rubia tinctorum Seed

The finished product of the plant Rubia tinctorum consists of rhizome and slices. The thickness of the root stems is 2-18 $\mathrm{mm}$ and the top is painted pink. When cross-sectioned, the bark is reddish, and the wood part is red. The product has a distinctive scent, first sweet, then slightly bitter and bitter. Root colored water brown, Rubia tinctorum Underneath Figure 2

Rubia tinctorum contains $13 \%$ moisture content, ash 10\%, other parts of rhubarb (stem, leaf, etc.) $1.5 \%$, organic compounds more than $1 \%$, and mineral mixtures more than $1 \%$, Anthaglycosides (combined in glycoside) Not less than $3 \%$. [1-4] 
Rubia tinctorum is a rhizome chemical. Contains 5-6\% of anthracene derivatives (alizarin, ruberitrinic acid, galiosine, purpurin, xantopurpurin, pseudopurpurin, rubiadin-glucoside, munistine, lucidine, ibericin, etc.). In addition to anthracene seeds, organic acids in plant roots contain up to $15 \%$ of sugars, proteins, pectin, ascorbic acid, and citric, apple, and wine acids. In the ground, carbohydrates, phenolkarbonic acids and their derivatives are coumarin, anthraquinone, triterpenoids, flavonoids (quercitene, c Campferol, apigenin). Iridoid and flavonoids in leaves; rutin and hyperoside in flowers. in ashes - 11.3\% (macroelements $\mathrm{mg} / \mathrm{g}$ ): $\mathrm{K}-28.8, \mathrm{Sa}-19.3, \mathrm{Mg}-1.9, \mathrm{Te}-2.5$. Micronutrients: $\mathrm{Mn}-0.43, \mathrm{Cu}$ 1.71, Zn- 1.43, Co - 0.04, Cr - 0.65, Al - 0.5, Ba - 2.01, V - 0.46, Se - 0.50, Ni - 0.63, Sr - 0.60, Pb - 0.13, I - 0.09, B - 43.6 $\mathrm{mcg} / \mathrm{g}$.

Ruberitrinic acid is a glycoside and, when hydrolyzed, breaks down to alizarin aglycone and disaccharide of primerose (which is composed of sugars and glucose, respectively).

Rubia tinctorum has medicinal effects on spasmodic and urinary incontinence and in the kidney stones (phosphates). For this reason, medicines are used in diseases of the urinary tract, breast cancer and gallstone and gout. This feature of the plant can be explained by the presence of flavonoids, terpenoids and other compounds.

Rubia tinctorum herb powder (powder), dry extract (extracted in pills). cysteine and other drugs. [1-4]

In addition to its medical use, the Rubia tinctorum is used in the production of silk curds and cotton, which are used in the production of cotton yarn, glam, cloth and materials as natural paints. Figure 3 .
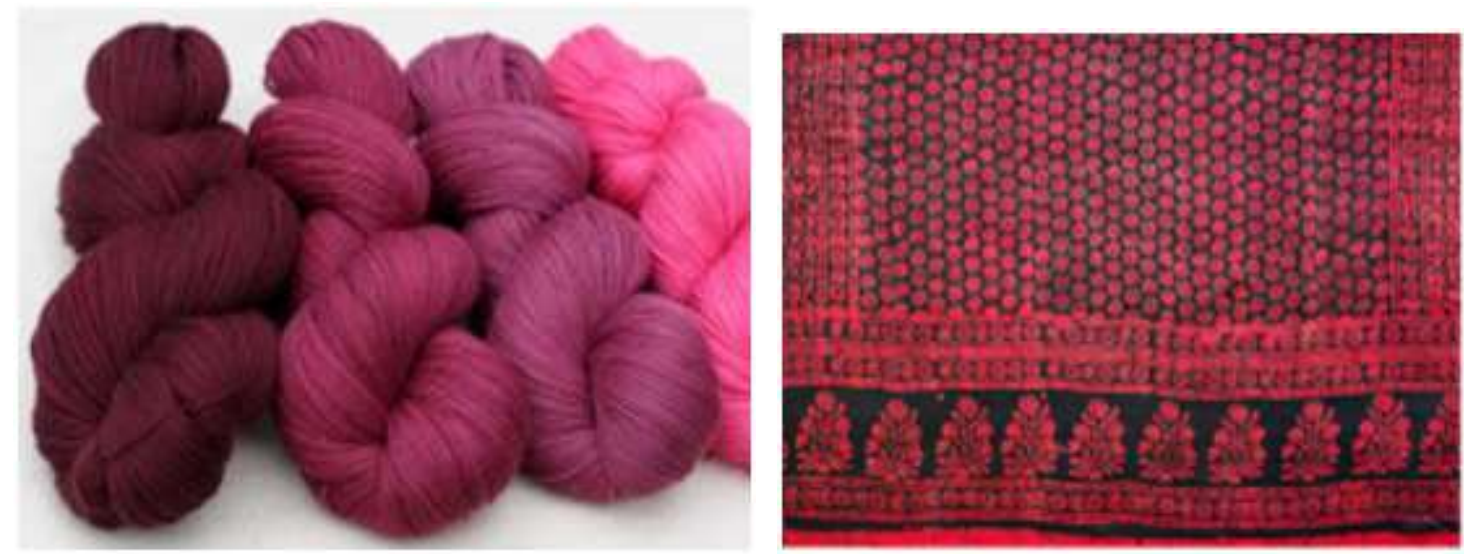

Figure 3: Rope and glam painted with natural chemicals isolated from the Rubia tinctorum plant

\section{Processing of Experimental Results}

Currently, many scientists in the Republic are conducting research on the biology and medicinal plants of the Republic of Uzbekistan. For introduction, we present the procedure and nutritional composition of the cultivation of the Rubia tinctorum plant under acne vitro conditions: Intensive green sprigs or ripe cuttings serve as the primary material for the production. Sterilized in $70 \%$ ethanol for $30 \mathrm{sec}$, without touching the three parts of the green bud, followed by a 4-6 min diocyte concentration (1: 1000) followed by washing 3-4 times for $10 \mathrm{~min}$. The nutrient medium of the biological test tube 22/200 (10 ml of tube) is as follows: $\mathrm{KNO}_{3}-950 \mathrm{mg} / \mathrm{l} ; \mathrm{NH}_{4} \mathrm{NO}_{3}-412 \mathrm{mg} / \mathrm{1} ; \mathrm{MgSO}_{4} 7 \mathrm{H}_{2} \mathrm{O}-185 \mathrm{mg} / 1 ; \mathrm{CaCl}_{2} 2 \mathrm{H}_{2} \mathrm{O}-440 \mathrm{mg}$ / 1; $\mathrm{KH}_{2} \mathrm{PO}_{4}-68 \mathrm{mg} / \mathrm{l}$; Fe -ellate, trace elements on Murasige-skug, mesoinositis - $50 \mathrm{mg} / \mathrm{l}$; thiamin - HCl-0.2 mg / 1; nicotinic acid - $0.2 \mathrm{mg} / 1$; pyridoxine $\mathrm{HCl}-0.2 \mathrm{mg} / 1$; indolyl acetic acid - $0.5 \mathrm{mg} / \mathrm{g}$; ferriculic acid - $1 \mathrm{mg} / 1$; sucrose - 10 $\mathrm{g} / 1$, if - $7.5 \mathrm{~g} / \mathrm{l} ; \mathrm{pN}-5.8$. The testicle is planted for 16 hours of light, with a temperature of 25-28 0C and daytime 20-22 0C. From the green shoots of the branches, the roots and branches of 4-8 shoots sprout for 40-60 days. If there is 
insufficient primary inputs, the plant grown in the test tube will be cut and re-planted, the nutrient content will be the same, and the amount of indole acetic acid $(0.2 \mathrm{mg} / \mathrm{l})$ will be reduced. The in vitro plant is transplanted into the greenhouse substrate. The substrate consists of two layers of sand and wood bark. The top of the substrate is a simple substrate, with a 4-5 cm thick layer of wood chips. (wood chips evaporate for 1 hour before insertion). In hydroponics, large river sand or diorite is used when substrate is used. The plant is removed from the test tube, rinsed with water and sown at $15-20 \mathrm{pcs} / \mathrm{m}$ 2. During the first 12-13 days, direct seeding should be avoided, the film will be covered with a film 30-60 cm above the substrate to increase moisture content. Once a day the film is removed and ventilated for several minutes. (At this time the leaf leaves should be wet). Depending on the temperature, irrigation 1-2 times a day. If the greenhouse is equipped with artificial fog, there is no need to cover the plant with film. In the first 30-60 days, the root system develops in the upper layer of the substrate. Depending on the biological nature of the variety and the timing of planting, the ripe branches of the greenhouse reach 0.4-0.5m. In the autumn, the seedlings are dug out of the greenhouse and planted in the open field. [5-7].

Today the President of our country Sh. Mirziyoev pays great attention to the cultural reproduction of medicinal plants in the Republic, introduction of new species, acclimatization and establishment of large-scale plantations, preparation of raw materials and further development of the pharmaceutical industry. The Decree of the President of the Republic of Uzbekistan dated March 20, 2018 No PP - 36/17 was signed. The Decree sets out a number of objectives for the sustainable use of natural resources of medicinal plants in flora of the Republic of Uzbekistan, including the organization of plantations of certain medicinal plants and increasing the volume and processing of their raw materials.

Development and reproduction of the Rubia tinctorum planting technology In the fields allocated to the Rubia tinctorum plant, in the early autumn, 10-15 tons of organic fertilizers, superphosphate, are pumped to a depth of $27-30 \mathrm{~cm}$ before each dew. It is advisable to plant $30 \mathrm{~kg}$ of nitrogen and potassium fertilizer per hectare while plowing on rainforest soils with less rainfall. [8]

Rubia tinctorum is also grown from seeds and rhizomes. Seeds are sown after sowing for 12 hours in a mixture of potassium perimanganate and copper solution in $0.002 \%$ solution. In the early spring plots are cultivated by boron, porridge and cultivation. When the soil temperature is $10-12{ }^{\circ} \mathrm{C}$ in the middle of March, $13-15 \mathrm{~kg}$ of seeds are used per hectare. It should be at least $4-5 \mathrm{~cm}$ deep. The seed capacity should not be less than $75-80 \%$.

Seeds sprout within 10-12 days if the soil temperature is normal and the humidity is sufficient. If the rhizome is grown from cuttings, its yield capacity should be at least 80-90\%. Roots should be sown in early spring at a depth of 8-10 $\mathrm{cm}$. An average of 10-12 centners per hectare is spent on rhizomes. The density of the plant is 10-15 units per 1 meter. When the seed and pencil are sown in the range of $60 \mathrm{~cm}$, in the second and subsequent years the plant will develop well and allow for full coverage of the soil surface. [8]

The Rubia tinctorum plant is irrigated 7-8 times in the first year and the number of irrigation in the following years is reduced. In the first year, the plant is softened and removed from weeds.

The first fertilization is carried out in May and June with $30 \mathrm{~kg}$ of nitrogen per hectare and $20 \mathrm{~kg}$ of potassium fertilizer per hectare. The second feeding will be completed in August with $30 \mathrm{~kg}$ of nitrogen and $20 \mathrm{~kg}$ of superphosphate fertilizer. Plant feeding is done before irrigation. During the second and third years of the dyeing rhizome, the first fruits are harvested when they turn dark and do not let them fall apart. Roots and rhizomes are removed in late autumn or early spring with a plug of $30-35 \mathrm{~cm}$ to remove the soil, washed with water, and dried at $45-50{ }^{\circ} \mathrm{C}$. Rubia tinctorum plant leaves 

the Composition, Biological Features and Extracts of Micro and Macroelements

are harvested manually or in mechanisms. An average of 80 to $100 \mathrm{~kg}$ of seeds and 13 to 14 centners of dry roots per hectare can be harvested. [8]

Macrophages and quantities of micro elements in the root of the plant Rubia tinctorum L. "Optical emission spectrometer with inductively coupled argon plasma was performed using Optima-2100DV (USA). Sample solutions for this were delivered to the wells in the autosystem, and final processing is performed by the Win-Lab (offline) apparatus. The device automatically calculates the noise, the form of the solution at the specified locations of the studied elements. The obtained results and spectrum analysis were performed automatically by "multispectral analysis". The results of these studies are presented in Table 1.

Table 1: A number of macro- and micro-elements contained in the root of the plant Rubia tinctorum $L$

\begin{tabular}{|c|c|c|c|c|c|}
\hline № & Items & $\begin{array}{c}\text { The amount of macro } \\
\text { and micro elements } \\
\text { in the root of the } \\
\text { plant }\end{array}$ & № & Items & $\begin{array}{l}\text { The amount of } \\
\text { macro and micro } \\
\text { elements in the } \\
\text { root of the plant }\end{array}$ \\
\hline 1 & $\mathrm{Al}$ & 451.110 & 22 & $\mathrm{~S}$ & 161.204 \\
\hline 2 & $\mathrm{Ba}$ & 41.515 & 23 & $\mathrm{Ti}$ & 27.613 \\
\hline 3 & $\mathrm{Bi}$ & 0.020 & 24 & $\mathrm{Gr}$ & 3.924 \\
\hline 4 & $\mathrm{Ca}$ & 94970.086 & 25 & $\mathrm{Co}$ & 0.437 \\
\hline 5 & $\mathrm{Fe}$ & 874.553 & 26 & $\mathrm{Cu}$ & 6.610 \\
\hline 6 & $\mathrm{~K}$ & $\mathrm{~S}$ & 27 & $\mathrm{Ga}$ & 1.917 \\
\hline 7 & $\mathrm{Li}$ & 1.128 & 28 & $\mathrm{Ge}$ & 0.008 \\
\hline 8 & $\mathrm{Mg}$ & 2402.037 & 29 & As & 0.258 \\
\hline 9 & $\mathrm{Na}$ & 734.728 & 30 & $\mathrm{Zr}$ & 0.422 \\
\hline 10 & $\mathrm{Mn}$ & 61.990 & 31 & $\mathrm{Nb}$ & 0.037 \\
\hline 11 & $\mathrm{Rb}$ & 11.740 & 32 & Mo & 0.242 \\
\hline 12 & $\mathrm{Se}$ & 0.121 & 33 & $\mathrm{Ag}$ & 0.038 \\
\hline 13 & $\mathrm{Sr}$ & 602.121 & 34 & $\mathrm{Cd}$ & 2.522 \\
\hline 14 & $\mathrm{~V}$ & 1.023 & 35 & In & 0.001 \\
\hline 15 & $\mathrm{Zn}$ & 7.699 & 36 & $\mathrm{Cs}$ & 0.079 \\
\hline 16 & $\mathrm{P}$ & 2139.666 & 37 & $\mathrm{Ta}$ & 0.005 \\
\hline 17 & $\mathrm{~Pb}$ & 1.609 & 38 & $\mathrm{~W}$ & 0.154 \\
\hline 18 & $\mathrm{Ni}$ & 5.889 & 39 & $\mathrm{Re}$ & 0.001 \\
\hline 19 & $\mathrm{Be}$ & 0.019 & 40 & $\mathrm{Hg}$ & -1.417 \\
\hline 20 & $\mathrm{~B}$ & 26.873 & 41 & TI & 0.041 \\
\hline 21 & $\mathrm{Si}$ & 541.173 & 42 & $\mathrm{U}$ & 0.049 \\
\hline
\end{tabular}

The data in the table show that 42 element heavy metals, macro and micro elements were found in the root of the plant Rubia tinctorum L. It is also shown in the table that the amount of $\mathrm{Ca}$ and $\mathrm{K}$ in the root of the plant is high.

\section{EXPERIMENTAL PART}

The number of macro and micro elements contained in the root of the plant was determined and studied on the Optima2100DV (USA) apparatus and the Perkin Elmer autosoder on the basis of the optical emission spectrometry method "Inductively coupled argon plasma." Rubia tinctorum L. root sample was thoroughly crushed, $0.1 \mathrm{~g}$ sample was weighed at $\square 1 \mathrm{mg}$ using analytical scales. The sample was placed in an autoclave made of Teflon and injected with $2 \mathrm{~mL}$ of nitric acid and $1 \mathrm{~mL}$ of hydrogen peroxide after autoclaving was thoroughly sealed and placed in a microwave breaker BERGHOF with the Speebwave TM MWS-3 + program (min. It is heated to ${ }^{\circ} \mathrm{C}$ and then cooled down to $25-40{ }^{\circ} \mathrm{C}$. After dissolution, Sample solution Autoclave 5-10 ml of anionized water LaboStar PRO UV 4, 1.51 / min, rinsed in 50 ml measuring tube 3 
times with water obtained from Evoqua (SG Wasser) and dehydrated in water until it reaches $50 \mathrm{ml}$. filled with free solution (2\% nitric acid). After receiving data from the device, the final processing is done by the Win-Lab (offline). The device automatically calculates the noise, the form of the solution at the specified locations of the studied elements. The standard uses a multi-element standard solution. The analysis is repeated 5 times and the arithmetic mean. The RSD for each item should be between 0.01 and 1.0\%. S-200 used in Perkin Elmer autosystem, generator power - $1500 \mathrm{~W}$, pump peristalysis speed $-1.2 \mathrm{ml} / \mathrm{min}$, argon flow $12-151 / \mathrm{min}$, plasma observation point $-0.81 / \mathrm{min}$.

\section{CONCLUSIONS}

- Good results were obtained using the in vitro method for introducing the Rubia tinctorum L plant.

- Studies on the root and root content of Rubia tinctorum L. on the Optima-2100DV (US) apparatus based on the "Inductively coupled argon plasma" optical emission spectrometry method and the autodosator S-200 Perkin Elmer instrument. quantities of macro and micro elements.

\section{REFERENCES}

1. Justin Rastheniy. V6 t. T. 5. Ch. 2. Red Light/Pod red. A. L. Taxonomy. -M .: Prosveshchenie, 1981. - p. 358.

2. Botany. Encyclopedia "All Time" / Pier. s angl. (ed. Grigorev D. i dr.) -Conemann, 2006 (Russian Studies). -S. 802. - ISBN 38331-1621-8.

3. Pharmacognosy (H.Kholmatov, U.Ahmedov) Abu Ali ibn Sino Tashkent 1997.

4. H.Kholmatov, UAAhmedov, Pharmacognosy: Textbook, Tashkent, Ibn Sina NMB, 1995.

5. Vysotsky VA, Tarashvili E.T. Microremnology zdorovogo posadochnogo material material yagodny kultur. - Sadovodstvo, 1982, No. 3 .

6. Golodriga P.Y., Zlenko VA, Butenko RG, Levenko B.A. Weighted Horns Hepotipov Vinogra. - Sadovodstvo, 1982, No. 3.

7. Kataeva NV, Avetisov VA Cloned Rasteniye and Cultured Fabrics. Cultura rochenia. - M.: Nauka, 1981. 4. Litwak AI, Kuzmenko A.P. Cultured cellulite, organ and vinograde in vitro. - Vb .: Selection of breeds in vinograde. Kishinev: Shtiintsa, 1982.

8. O. Ahmedov, A. Ergashev, A. Abzalov. Technology of medicinal plants and their cultivation. Tashkent - 2008. B. 164 